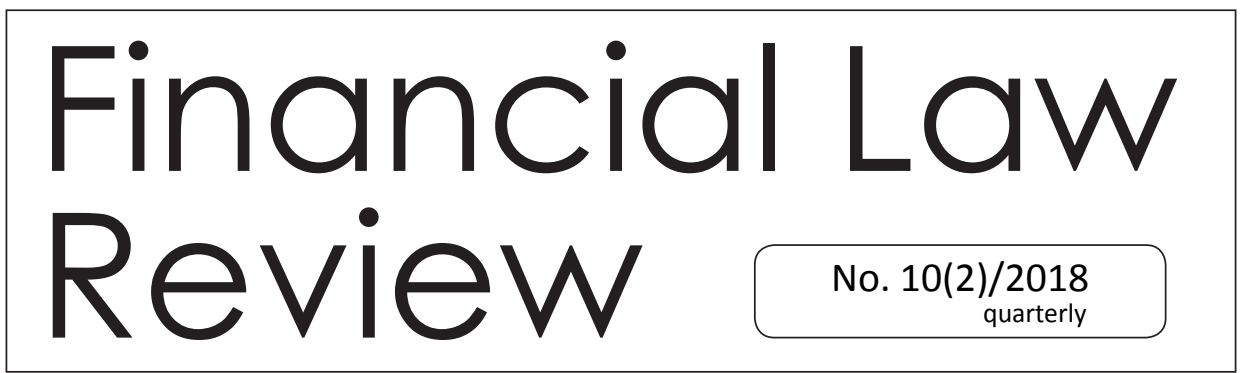

UNIVERSITY OF GDAŃSK • MASARYK UNIVERSITY • PAVEL JOZEF ŠAFÁRIK UNIVERSITY • UNIVERSITY OF VORONEZH http://www.ejournals.eu $\bullet$ http://czasopisma.bg.ug.edu.pl

\title{
THE CONCEPT OF DEVELOPMENT OF HUMAN RIGHTS IN THE SPHERE OF PUBLIC FINANCE IN THE RUSSIAN FEDERATION NATALYA POVETKINA*
}

\begin{abstract}
The article is devoted to the identification of trends in the development of budget law-making in the Russian Federation. The purpose of the article is to identify the main vectors (trends) characteristic for the development of modern lawmaking and law enforcement in the field of public finance. The article focuses attention on the most popular areas of law-making in the budgetary sphere - on information technologies and systems, as well as on legal instruments aimed at improving the efficiency of administering public finances and using budgetary funds. The problem of correlativity of various aspects of public finance is stated, legal exemptions (features) in regulation of public finance are revealed. The methods used include formal logical method, comparison, analysis, synthesis, comparison, generalization.
\end{abstract}

\section{Keywords}

budget lawmaking, budget legislation, public finances, development tendencies, information systems, information technologies, budget control, efficiency of budget funds.

JELClassification: H6, H72, K39

* Doctor of Law, Associate Professor, Head of the Department of Financial, Tax and Budget Legislation of the Institute of Legislation and Comparative Law under the Government of the Russian Federation, financial law, budget law; 6 monographs, more than 50 articles; pna127@mail.ru 


\section{Introduction}

Legislation in the field of public finance, especially in the past decade, is characterized by extreme dynamism and mobility. The existing model of legal regulation of public finance is under the projection of the influence of various factors such as the state of the economy, the political situation, the geopolitical situation, and a number of other circumstances that condition their transformation and determine the vectors of their development. The absence of a common system-forming normative legal act, which determines both general approaches, requirements, and specific legislation in the field of public finance, does not contribute to the stability and sustainability of the development of legislation in this area.

Taking into account that neither the current legislation nor the subordinate regulatory legal regulation defines the concepts of "public finances", we consider it expedient to fix this concept with a view to a uniform understanding and subsequent definition of the scope for establishing the boundaries of legal regulation.

Categories "public finances", "statefinances", "socialfinances" are most often used in the official circulation in the context of identity with budgetary funds. Without delving into the subtleties of the etymological interpretation, we note that for each of these categories there is a direct or indirect proximity to the definition of "budget funds". The analysis of normative acts using these concepts allows us to draw identical parallels in the understanding of all these concepts. At the same time, in our opinion, such identification is unacceptable, primarily because of their belonging to different subjects and their various substantive correlations with each other. Thus, public finances (just like municipal finance) belong exclusively to public-territorial formation (to the state, municipal formation) and can be completely identified with the notion of "budgetary funds". Public finance is a meaningful broader concept and includes not only budgetary (state, municipal) funds, but also financial means of state corporations (companies), public-law companies and other subjects created by the state (municipal entity) for the performance of public tasks and functions (tasks and functions of the state (municipalities).) Public finance is the content of the broadest category and consolidates public finances, private finance ${ }^{2}$ and the finances of various organizations (usually

1 There is no normative legal definition of this concept. An analysis of budget legislation allows us to conclude that budgetary funds are the funds of the corresponding budget of the budgetary system of the Russian Federation.

2 Private finances are not the subject of this study, since they are not subject to legal regulation of financial legislation and serve the achievement of public goods in a very narrow sense exclusively as a source of payment of mandatory payments to the budgets of the budgetary system of the Russian Federation, respectively, are mediated by budgetary funds and thereby 
non-state ownership) used to achieve the immediate public good (for example, various charitable foundations formed from private payments but used to finance the social functions of the state.) Based on the above, the architecture of finance can be represented as follows ${ }^{3}$ : public finances - state (municipal) finances (budgetary funds).

As the main problem in the legal regulation of the chosen sphere, we have to state some randomness and precision in legal regulation, comparable to the forced "patchwork quilt". The expansion of the scope of legislative and regulatory legal acts in the sphere of public finance has, on the one hand, quite understandable reasons related to the fact that public finances are the foundation (foundation) for the implementation of absolutely all other spheres of state activity, have a strategic purpose - only in conditions of effective (sufficient, qualitative) financial provision, it is also possible to effectively develop both other spheres and the sphere of public finances (so-called self-sufficiency), which depends on a number of factors (risks, threats, challenges) (Kucherov, Povetkina (eds.), 2017) - the quality of legislation and its application; management effectiveness; sufficiency of the measures taken to ensure (control, coercion); the state of national (economic (financial) security, the political situation, the state of the economy, etc. On the other hand, despite the dynamics, the legislation should be stable, predictable and understandable.

In this regard, it seems necessary to identify the main trends in the development of lawmaking and the existing enforcement of public finance in order to subsequently develop proposals and recommendations aimed at improving the quality of regulations and their implementation.

\subsection{Legal exceptions in the regulation of public finance}

The sphere of public finance is unique and very specific, which also causes a number of peculiarities in its normative legal regulation, which is derived from traditional approaches to regulatory legal regulation. For example, in the sphere of strategic planning, Federal Law no. 172-FZ of June 28, 2014 (as amended) "On Strategic Planning in the Russian Federation" refers to the strategic planning documents developed within the framework of the goal-setting on the sectoral and territorial principle, other and budgetary forecast of the Russian Federation for a long-term period, but unlike other documents (including strategic planning

serve the public benefits. Nevertheless, private finance from the position of a systemic approach cannot be excluded from the species diversity of public finances.

3 The design is presented from the general to the particular. 
documents developed at the federal level) is limited solely to its fixation in the list of such documents and does not establish the main conditions (requirements) for it, but contains a reference rule that the budget forecast is developed in accordance with the Budget Code of the Russian Federation. Similar legal violations are also observed in other spheres (a special procedure for calculating the limitation period for bringing to administrative responsibility for violating the budget legislation of the Russian Federation and other normative legal acts regulating budgetary relations (Administrative Code of the Russian Federation, Art. 4.5), a special procedure for the adoption and amendment of regulatory legal acts in particular, it is stipulated that the introduction of amendments to the Budget Code of the Russian Federation, as well as the suspension, cancellation and recognition of the provisions of the Budget Code of the Russian Federation are implemented by separate federal laws and cannot be included in the texts of federal laws that modify (or suspend, cancel, revoke, invalidate) other legislative acts of the Russian Federation or contain an independent subject of legal regulation (Budget Code of the Russian Federation, Art. 2), a special procedure for the execution of judicial acts on the foreclosure on the budget of the budgetary system of the Russian Federation, the consolidation of the legal regime of budget immunity (Budget Code of the Russian Federation, Art. 239, Chap. 24.1), etc. Moreover, the draft federal law "On State Control (Supervision) and Municipal Control in the Russian Federation" also derives control (supervision) in the sphere of public finance from the subject of regulation of this project.

\subsection{Lawmaking and law enforcement in the conditions of "digital" reality}

Information systems and technologies are rapidly penetrating into the modern legal reality and in many ways predetermine the ways of its transformation. The sphere of legal provision of public finance is no exception and is dynamically developing in the age of digital technologies. In the conditions of global digitalization of all spheres of activity in most countries of the world and the rapid penetration of information systems and information technologies into public finance, a transformation of budget relations takes place, requiring the search for the most optimal forms of legal regulation.

The development and implementation of information systems in the field of public finance occurs consistently and is caused by the objective needs of society and the state, as well as the need to increase the transparency of public finance and with varying degrees of coverage the areas of public finance (for example, one of the very first areas in which digital technologies have been successfully applied 
and are actively developing is the tax). At the same time, the opinion expressed in science about the inadequacy of establishing the emergence of a kind of "crosssectoral" legal norms that ensure the "flashing" of the right to the goals and tasks of the digital economy (Khabrieva, Chernogor, 2018: 85-102) is absolutely just. Since it is really "important to understand not only how and with what effect they will affect public relations, the will and consciousness of people, the development and dissemination of digital technologies, but also how they will behave within the system of law, what kind of relations these norms create and what place they will occupy in the system of law "(Khabrieva, Chernogor, 2018: 85-102). Such a statement of the problem finds its expression in the sphere of public finance. At the same time, the introduction of such a state information system as the Electronic Budget can be viewed as an optimistic example of not even the emergence, but the implementation of a cross-sectoral set of budget norms that permeate other branches of legislation affecting them and forcing them to transform into action. It is possible to illustrate this thesis, for example, by legalizing the list of subsystems (components, modules) of the state integrated public finance management information system "Electronic Budget" and the related responsibilities for filling in electronic mode the component of the formation of government tasks for the provision of public services works) and reports on their execution or the module for the formation and maintenance of registers provided for by the Federal Law no. 44-FZ of April 5, 2013 "On the contract system in the procurement of goods, works, services to ensure state and municipal needs" (Order of the Ministry of Finance of Russia no. 110 of July 07, 2016). In this regard, it is difficult to overestimate the importance of the development of information technologies in the budgetary sphere from all spheres of the state activity that are subject to "digitization", since it is obvious that the most important prerequisite and prerequisite for the formation of a new model of economic growth in priority is precisely the longterm sustainability of the budgetary system of the Russian Federation.

The establishment of the foundations of financial, tax and budgetary legislation is the sole responsibility of the Russian Federation (for example, the unified bases of financial legislation are consolidated, the administration of all taxes of the tax system of the Russian Federation is carried out by the Federal Tax Service; the Federal Treasury ensures the implementation of the principle of unity of the cashier fixed in the Budget Code of the Russian Federation and executes the budgets of all levels of the RF budget system) and predetermines the creation of state information systems in the sphere of public finance created primarily on the basis of legal acts of state bodies to achieve the goal formulated by the Federal Law 
no. 149-FZ - the exercise of the powers of state bodies and ensuring the exchange of information between these bodies. It should be noted that due to the multiplicity of existing information systems that "serve" public finance, each of them has more and more specific goals for their functioning.

Taking into account the increased attention to the safety of public finances, their effective and transparent use, much attention is paid in this sphere to the observance of budgetary discipline and control over the spending of budgetary funds. In this regard, the introduction of information systems (information technology) allows, in maximum coverage, to ensure the stability and (or) continuity of the budget classification of the Russian Federation, as well as to ensure comparability of the budget indicators of the reporting, current and next fiscal year, necessary for budgetary control, public control of citizens for the execution of the budget.

Moreover, the objective need for the "digitization" of budgetary legal relations led to the development of a fundamentally new chapter in the draft new edition of the Budget Code of the Russian Federation - Information support of the budgetary process (Chapter 18), which states that in order to inform the budget process, information systems will be created and maintained in the area of public (municipal) finance management, including federal state information system, which in conjunction with other information systems will ensure the implementation of the budgetary powers of the budget process, provided the RF Budget Code, budget authority (autonomous) agencies and recipients of funds from the budget, as well as the principle of accountability and transparency (openness) subjects of information systems. The following principles of functioning of information systems are fixed: 1) the completeness, reliability, timeliness of information generation in information systems and the general availability of such information, with the exception of information access to which is limited by federal laws; 2) the single entry of information into information systems in the sphere of public (municipal) finance management; 3 ) the interaction of information systems in the management of public (municipal) finances and other information systems; 4) accessibility and freedom of software tools of the federal state information system in the sphere of management of state (municipal) finances, necessary for the subjects of information systems in order to realize their budgetary powers and the formation of information required for inclusion in the federal state information system in the field of public administration (municipal) finances; 5) use of electronic signature in information systems in the sphere of public (municipal) finance management to ensure legally significant electronic document circulation; 6) application of unified registers, classifiers and directories in information 
systems in the sphere of public (municipal) finance management, as well as compliance with unified requirements and rules for the implementation of budgetary powers using information systems in the management of public (municipal) finances.

Ensuring the information security of information systems in public finance is based on general security requirements, and has a well-developed regulatory framework (Act on Information, Information Technologies and Information Protection), which is based on a risk-based model.

Information system as a set of information contained in databases and providing information technology and technical means processing, just like information technologies as processes, methods of searching, collecting, storing, processing, providing, disseminating information and ways of implementing such processes and methods (Act on Information, Information Technologies and Information Protection), maintaining common advantages and characteristics (speed (speed), comparability of data, economy, convenience, transparency, continuity, reliability, excluding duplication), refracting through the prism of public finance, acquire specific shades and a special purpose, conditioned by the most important role of the budget for the state. Thus, the peculiarities of budgetary relations make it possible to single out the following main specific features of implementation in the sphere of public finance.

1. The functioning of information technologies in the sphere of public finance is mediated by the budgetary activity of the state and reflects the state structure, features of the Russian legal system;

2. Due to the need to implement the principle of openness and transparency (Povetkina, Khazova, 2014: 11-17), enshrined in the "Financial Constitution of the Russian Federation" - the Budget Code of the Russian Federation, which, in addition to general approaches to mandatory publication of a law on the budget, society and the media of draft budgets and procedures for their consideration and adoption, there is a requirement to provide access to information located in the information and telecommunications network of Intel "on a single portal of the budgetary system of the Russian Federation. A reservation should be made on the existence of a restrictive nature of this principle, since secret articles that are not subject to publication and placement in the above network (and the existence of a closed piece of information contained on a single portal of the budget system of the Russian Federation) may be approved in the federal budget; 
3. Periodicity (cyclicity) is determined by the budgetary period of the budgetary process, which has a cyclic, repetitive, continuous nature, which in turn depends on the need for constant financial support for the tasks and functions of the state;

4. Target orientation of the functioning of information systems and the use of information technology in public finance. The use of information technologies in the sphere of public finance can be conditionally divided into two planes: the first - ensures the quality and efficiency of public finance management (SIS "Electronic Budget") and is intended for use by authorized entities (participants and operators), the second - provides adaptation and understanding of specific matter for the population (the budget for citizens) and is intended exclusively for the "civilian" target audience.

In addition, taking into account the specific nature of the subject composition of the public finance sector, due to the exclusion of citizens from participants in budgetary legal relations, it can be stated that this category of subjects is more of an observer (user), a "visual" user, rather than a real participant in the system (users only have an opportunity to view and analyze information, participate in surveys, forums).

The architecture of information resources in the sphere of public finance can be represented as follows.

It seems advisable to carry out structuring according to the principle of either direct "digitization" of the budgetary sphere or a relationship indirectly related to it, but which has an effect on targeted, transparent and efficient spending of budget funds.

The first group of information resources can include the state integrated information management system of public finances "Electronic Budget" (Act on the State Integrated Information Management System for Public Finances "Electronic Budget"), the state information system on state and municipal payments; ${ }^{4}$ The Information and Analytical System of the Federal Treasury (http://www.roskazna.ru/gis/informacionno-analiticheskie-sistemy-federalnogo-kaznachejstva/); information site "Budget for citizens" (http://budget.open.gov.ru/). The second

4 Analysis of information from the official site of the Federal Treasury allows us to conclude that this system is included in the structure of a more global system - the state automated information system "Management", while the structure of SAIS "Management" does not include it in its composition, while the operator of both systems is unequivocally defined - the Federal Treasury. 
group may include: the federal information system of strategic planning (Decree of the Government of the Russian Federation of November 27, 2015 No. 1278); State automated information system "Management" (Act on the State Automated Information System "Management"); information site for posting information about state (municipal) institutions (http://www.bus.gov.ru/pub/); a unified information system in the field of procurement (http://zakupki.gov.ru/).

Summarizing the foregoing, we note that the sphere of public finance successfully undergoes a comprehensive "digitization" and this, in turn, allows us to speak of the federal budget ${ }^{5}$ as a "digital budget"; legal registration of the "digital budget" consists of multi-level and complex regulation and is built on an interdisciplinary approach, is in the active development stage and occurs within the boundaries of the general digitalization of the spheres of the state activity, taking into account the specifics specific to budgetary activity; in the field of public finance there is no unified structured information system that allows logically and consistently to trace the mechanism of the functioning of information resources in the form of an understandable and harmonious design; there is some heterogeneity of the implemented information systems that have their own special purpose, which creates additional risks for achieving the established goals of implementing information systems, including ensuring the implementation of the principles of transparency and unity, improving the quality of monitoring (monitoring) of budgetary activities, etc.

\subsection{Development of legal instruments aimed at improving the efficiency of administering public finances and using budget funds}

Various crisis situations faced by the Russian Federation, cause the transformation of priorities in the direction of lawmaking work on the regulation of public finance. This urgently requires the development and consolidation of such legal instruments that would most efficiently, timely, qualitatively and in full allow the formation and use of public financial funds. In our opinion, such a legal tool as internal state financial (budgetary) control is in demand the most at the moment.

Reforming the system of bodies that implement internal state financial control has led to a change in approaches to its implementation and the transformation of legal regulation. The three-year period after the Federal Treasury is given the authority to implement this type of control allows us to summarize the preliminary

Due to the gradual introduction of the SIS "Electronic Budget" there is a consistent integration of this system at the level of regional budgets (it was planned to be completed by January 1, 2018 and budgets of municipalities (planned by January 1, 2019). 
results of such a reform, identify trends in the development of the control activities of this executive body and identify problems of legal regulation.

Analysis of the activities of the Federal Treasury as the main body that implements direct internal state financial (budgetary) control allows us to single out the following main directions of development of legal regulation and enforcement of this sphere.

1. Actual shift of priority in the implementation of internal state financial (budgetary) control from the subsequent to the preliminary. So, even at the stage of preparation for the transaction in the framework of budget monitoring ${ }^{6}$, the terms of the disclosure of the structure of the price of the state contract, the amount of the subsidy (contribution) under the agreementare included in the agreements; on the conduct of separate accounting of the results of financial and economic activities; on the implementation of payments after the Federal Treasury carried out a check (the terms of contracts, documents for opening an account, a statement of expenditure in terms of planned, and then actual indicators, grounds, the fact of supply of goods, performance of work, provision of services), etc.).

2. Direct participation of the Federal Treasury as the body of the budgetary system that executes the budgets and as an organ of internal state financial (budgetary) control, primarily through the phased introduction of treasury support into the budget process, in the entire chain of budgetary funds flow from the budget of the budgetary system of the Russian Federation totheirfinal recipient in achieving the ultimate goal (observance of the principle of the targeted nature of budgetary funds). This allows to ensure transparency, efficiency, targeted use of budgetary funds and excludes the possibility of corruption offenses.

3. Enhancement of cooperation in the implementation of internal state financial (budgetary) control - within which the most active is the interaction with Rosfinmonitoring (for example, in terms of informing about organizations and individuals belonging to the risk group for which there is evidence of their involvement in extremist activities or terrorism) and the Federal Tax Service (also

6 Budget monitoring - collection and analysis of information on the subject and activities of the subject of budget monitoring on a systematic and regular basis, including the continuous collection and analysis of data from the federal state information system in the area of public (municipal) finance management "Electronic Budget" (hereinafter - SIS “Electronic budget"), state information systems administered by subjects of budget monitoring, on the operations and activities of budgetary entities displayed in these systems itoringa, in order to prevent violations of the budgetary legislation of the Russian Federation 
in terms of informing about the risk group from among taxpayers for whom there is data on tax evasion in the existing receivables, about finding in the register of unscrupulous suppliers, which becomes especially important with treasury support), etc.

4. Active implementation of the risk-oriented approach in the implementation of internal state financial (budgetary) control. A Treasury risk management concept has been developed that assumes such ways of responding to risks as risk acceptance, risk avoidance, risk transfer, risk control, risk monitoring, control of the effectiveness of the risk management system, treasury risk management culture and information interaction.

5. The standardization of approaches to the identification of violations in the budgetary sphere is also carried out, the Classifier of violations (risks) identified by the Federal Treasury in the course of monitoring in the financial and budgetary sphere is developed, which allows them to be systematized and digitized. In turn, the introduction of digital technologies in this area will inevitably lead to increased financial discipline, the effectiveness of control measures, facilitate the control load on participants and non-participants in the budgetary process, increase the efficiency of spending budget funds and reduce the risks of corruption manifestations in the budgetary sphere.

6.Introduction of information (digital) technologies in the implementation of internal state financial (budgetary) control, which allows to ensure transparency of implementation and activities, both in direct control and in the overall financial activity of the entities under control, and also increases the responsiveness of the control body to that or other risk (or violation).

\section{Conclusion}

1. To ensure transparency, the strength and stability of legal regulation and enforcement in the field of public finance will allow the adoption of the Fundamentals of the financial legislation of the Russian Federation, in which there will be unified principles for the legal and regulatory provision of both the basic and specific areas - public finance, including fixing key concepts (for example, the definition of the concept of "public finances"), their system; consolidation of the basic principles of their functioning; unified principles for the establishment and implementation of non-tax payments; a system of legal instruments aimed at transparent and quality administration of revenues (for example, horizontal tax monitoring) and on transparent and high-quality expenditure of public finances 
(for example, a contract system in the procurement of goods, work, services for government and municipal needs and its treasury support, budget monitoring, etc.); unified approaches to the implementation of financial control (budgetary, tax, currency, banking supervision, financial monitoring, etc.). The adoption of this act will allow us to regulate not only the regulation of public finance, unify approaches to their understanding, but also provide a clear understanding and interpretation of the legislation in this area, which in turn will ensure effective enforcement in the field under investigation, increase financial discipline the stage of administration of income and at the stage of subsequent expenditure, eliminates the risks of corruption in public finance.

2. The rapid increase in the volume of regulatory legal acts in the sphere of public finance has led to an increase in the introduction of terms that do not meet the basic requirements of legal technology (inaccurately reflecting the meaning of the term and its main content, having an estimated or ambiguously understood character $^{7}$ ) in the legal field. Inventory of the terms used in the legislation on public finance and their unification will also improve the quality of interpretation, understanding and enforcement of these norms.

3. The multilevel normative legal regulation of the use of state information systems (in particular, SIS "Electronic budget"), the complexity of its interpretation and understanding for the "consumer" requires additional methodological support from the administrator of this system with respect to stakeholders in the correct interpretation and explanation of the application of legislation (subordinate regulatory legal acts) in this field.

4. The transformation of approaches to the activities on the implementation of the internal state financial (budgetary) has necessitated a change in its legal regulation, since only in legal forms it is possible to carry out control measures of any kind, at any level and in any form. As the analysis of normative acts regulating this type of control shows, detailed legal regulation of all "novels" - treasury support, budget monitoring, risk-oriented approach, etc. is carried out at the subordinate level (normative acts of the Ministry of Finance of the Russian Federation and the Federal Treasury) and do not have any fixation at the level of the basic act of budget legislation (in the Budget Code of the Russian Federa-

For example, ambiguous interpretation is caused by the following terms: public, public, public finances; correlation of concepts - financial monitoring, budget monitoring, horizontal (tax) monitoring; ambiguous understanding of the term cost effectiveness; the estimated concept of "debt sustainability", "stability of the budgetary system", "budgetary coercive measures" and a number of others. 
tion $)^{8}$. However, in our opinion, this circumstance is temporary, removable and is explained by the use in the "test" mode of these legal instruments of internal state financial (budgetary) control.

\section{References}

Кучеров, И., Поветкина Н. (Kucherov, I., Povetkina, N.) (eds.): Институты финансовой безопасности (Institutes of Financial Security), Москва: ИНФРА-М (Moscow: INFRA-M), 2017.

Поветкина, Н. Хазова, Е. (Povetkina, N., Khazova, Е.): Интегрированные информационные систему управления публичными финансами в обеспечении прозрачности бюджетной системы Российской Федерации (Integrated Information Systems for Managing Public Finances in Ensuring Transparency of the Budgetary System of the Russian Federation), Журнал российского права (Journal of Russian Law) no. 9 (2014).

Хабриева, Т., Черногор, Н. (Khabrieva, Т., Chernogor, N.): Право в условиях цифровой реальности (Law in the Conditions of Digital Reality), Журнал Российского права (Journal of Russian Law) no. 1 (2018).

\section{Legal Acts}

Act no. 149-FZ/2006, On Information, Information Technologies and Information Protection, as amended.

Act no. 658/2015, On the State Integrated Information Management System for Public Finances "Electronic Budget “, as amended.

Act no. 1278/2015, On the Federal Information System for Strategic Planning and Amendments to the Act on the State Automated Information System "Management".

Act no. 1088/2009, On the State Automated Information System "Management", as amended.

Act no. 110n/2016, On Approval of the List of Subsystems (Components, Modules) of the State Integrated Information Management System of Public Finances "Electronic Budget", as amended.

Draft act of Budget Code of the Russian Federation, https://www.minfin.ru/common/upload/library/2017/12/main/01_-_NRBK.pdf.

$8 \quad$ Legal regulation of treasury support is carried out annually (since 2016) by the Federal Law on the federal budget for the year and the planning period. In addition, it should be noted that the draft federal law on the introduction of treasury support in the contract system in the sphere of procurement of goods, works, and services for provision of state and municipal needs is currently being considered. In addition, the new version of the Budget Code of the Russian Federation also fixes these "novels". 